\title{
"Perhaps home is not a place but simply an irrevocable condition": At Home in the Life and Work of James Baldwin
}

\author{
Douglas Field University of Manchester
}

Keywords: James Baldwin, home, house, place, expatriatism

In one of the most poignant scenes captured in James Baldwin: The Price of the Ticket (1989), David Baldwin delivers a moving epitaph on his brother's legacy. As though channeling his recently departed brother, employing a poetic language hewn from the scriptures, David proffers his brother's last thoughts:

He said, "I pray I have done my work so, that when I have gone from here-and all turmoil, through the wreckage and rumble, and through whatever-when someone finds themselves digging through the ruins." He said, "I pray, that somewhere in that wreckage they'll find me; that somewhere in that wreckage that they can use something that I left behind. And if I've done that, then I've accomplished something in life."'

James Baldwin's humble meditation on his legacy invites readers to become archaeologists sifting through his life and work. A number of the essays in this volume explore Baldwin's legacy, and several others attest to the ways in which the author's writing is shot through with meditations on the question for home, described in Giovanni's Room (1956) as "perhaps ... not a place but simply an irrecoverable condition."2 In "Autobiographical Notes," the first essay in Notes of a Native Son (1955), Baldwin recalled how, aged 17, he left the church, and how, shortly after, he left his home in Harlem. "You don't have a home until you leave it," Giovanni tells David in Baldwin's second novel, "and then, when you have left it, you never can go back." 3

A soi-disant "trans-Atlantic commuter," Baldwin left the United States for Paris in 1948, remaining in France for most of his life, apart from an interrupted decade in Turkey during the 1960s. ${ }^{4}$ Although Baldwin died in St. Paul-de-Vence, near Nice, his home for the last seventeen years of his life, he dismissed claims that he was an 
expatriate writer, reminding readers that he had never relinquished his American passport. "You never leave home. You take your home with you," Baldwin insisted. "You better. Otherwise, you're homeless."

In Baldwin's early work, the concept of home is frequently intertwined with the church, or house of prayer. "But as for me and my house," his step-father, David Baldwin declared, "we will serve the Lord." One of Baldwin's earliest known short stories is called "In My Father's House," the original title of his first novel, which became Go Tell It on the Mountain (1953). In "Notes of a Native Son," originally published in Harper's magazine with the title "Me and My House," Baldwin recalls his step-father "sitting at the window, locked up in his terrors; hating and fearing every living soul including his children who had betrayed him, too, by reaching towards the world which had despised him."7 Baldwin's recollections of this period suggest that he was eager to join the world that his step-father rejected, and to leave his cramped Harlem house, which was ruled with harsh patriarchal authority. In Go Tell It on the Mountain, the young protagonist, John Grimes, dreams, like Baldwin, of becoming "a poet, or a college president, or a movie star; he drank expensive whisky, and he smoked Lucky Strike cigarettes in the green package."

In his later work, Baldwin explores the connections between the familial home and the metaphorical house of America where African Americans live in cramped servants' quarters. "This is your home," David tells his nephew in The Fire Next Time (1963). "Do not be driven from it," Baldwin writes, in an echo of John (14.2): "In my Father's house are many mansions ... I go to prepare a place for you." In The Fire Next Time, Baldwin's reference to his family home slips between disinterring memories of the house he shared with his siblings and something more abstract: "Let him laugh and I see a cellar your father does not remember and a house he does not remember." ${ }^{\prime 10}$ Here and elsewhere in Baldwin's writing, references to houses and rooms connect the familial home to broader questions about American history. Toward the end of the letter to his nephew, Baldwin quotes from the spiritual "Tree of Life," also known as "Hold On," where the cellar remembered from childhood is transformed into a symbol of racial emancipation: "The very time I thought I was lost, my dungeon shook and my chains fell off." 11 In The Fire Next Time, Baldwin famously asked, "Do I really want to be integrated into a burning house?," a theme that he developed in the late 1960s, which has regained relevance in the wake of recent race riots in the U.S.: ${ }^{12}$

That great western house I come from is one house, and I am one of the children of that house. Simply, I am the most despised child of that house. And it is because the American people are unable to face the fact that I am flesh of their flesh, bone of their bone, created by them. My blood, my father's blood, is in that soil. They can't face that. And that is why the city of Detroit went up in flames. And that is why the city of Saigon is under martial law.

I know that in 400 years in that house they do not know who I am, and I cannot marry their daughters, or go to their churches. ${ }^{13}$ 
Interest in Baldwin and the concept of home is not limited to academic study. There are campaigns afoot to rescue the seventeenth-century house in St. Paul-deVence where Baldwin lived from 1970 until his death there in 1987. Two wings of the property have been recently demolished to make way for luxury apartments. Campaigners are trying to raise funds to preserve what remains of the house and transform it into a writers' retreat. ${ }^{14}$ Visitors have flocked to the National Museum of African American History in Washington, D.C. to see a number of personal items owned by the writer, including his passport, issued in 1965, and an inkwell. In 2014, 128 Street, between Fifth and Madison avenues, was named "James Baldwin Place," a long-overdue commemoration of the writer's connection to Harlem.

In one of his most penetrating essays, "Stranger in the Village," Baldwin recounts spending a winter in the tiny Swiss village of Leukerbad, also called Loèche-lesBains. Baldwin's first trip there was during the summer of 1951, followed by two further trips in winter, where he finished his first novel, Go Tell It on the Mountain. On each visit to Leukerbad, Baldwin stayed in the chalet of his close friend, the Swiss painter Lucien Happersberger, the dedicatee of Giovanni's Room. Baldwin would also return to the village in the early 1960s to narrate his essay in French for a Swiss television company. ${ }^{15}$ First published in Harper's magazine in 1953, and then collected in Notes of a Native Son, "Stranger in the Village" is a poignant meditation on Baldwin's experience as the first black man to be seen by the Swiss villagers, where he was "simply a living wonder." ${ }^{16}$ In the essay, Baldwin meditates on the ways in which the impoverished and illiterate villagers are utterly at home in the West in ways that he could never be. The villagers "move with an authority which I will never have," Baldwin writes, "and they regard me, quite rightly, not only as a stranger in the village but as a suspect latecomer, bearing no credentials, to everything they have-however unconsciously-inherited." ${ }^{7}$

On 23 December 2017, I drove from Geneva to Leukerbad, a two-and-a-halfhour journey along quiet roads which are buttressed by what Baldwin described as "that absolutely alabaster landscape." ${ }^{18}$ There's a small tourist information shop near to the thermal baths mentioned in his essay but there is little information about the author, aside from copies of "Stranger in the Village" for sale in Swiss German. I enquired about Baldwin to the proprietors of local restaurants and bars, one of whom thought I was asking about James Bond, the other, Alec Baldwin. Wandering around the village, I stumbled across the "Ballet Haus," a building that Baldwin mentions in "Stranger in the Village," which is now a ski-hire shop. Close by is the Catholic church, where the villagers, Baldwin recalls, donated money to missionaries in Africa to "save" the natives. Eventually I found the home which belongs to the Happersberger family, a modest chalet nestled behind "Haus Goethe," sonamed after an earlier literary visitor. At breakfast on my final morning, I asked the hotel owner if he had known Baldwin; he replied that he had met him once through Lucien Happersberger, whose snowscape paintings adorned the walls of the dining room where I'd been eating.

Why is it so important to preserve Baldwin's homes and to set foot in the places where he lived and worked? There's the thrill of walking down a street that he must 
have trod; and there's the excitement about visiting places that Baldwin wrote about in his work: a sense of being closer to the writer; of sharing an experience and moment. There's also a danger that visitors to places inhabited by Baldwin will experience the frisson of, say, drinking in a bar that he frequented, but will leave without any greater understanding of his life and work-just as Baldwin critiqued protest fiction, which claims to effect change but rarely engenders praxis. The protest novel, Baldwin points out, "so far from being disturbing, is an accepted and comforting aspect of the American scene, ramifying that framework we believe to be necessary." ${ }^{19}$ There's an implicit assumption that readers of Baldwin's work, who will have access to more of his papers at the Schomburg Center for Black Research and Culture, and who can visit the sites of his various homes, can amass these details to finally assemble what Quentin Miller has called the "half-finished jigsaw puzzle" of the writer's life and work. ${ }^{20}$ Paying attention to the environments that produced Baldwin may teach us more about his life and work, but it will require time and effort-and much more than a day trip to the South of France or Switzerland. Baldwin's writing is frequently deceptive; his piercing clarity gives coherence to what he called "the disorder of life" even as we dig through his ruins. ${ }^{21}$

Baldwin's declaration that home is "perhaps ... not a place but simply an irrecoverable condition" is far from straightforward. With brutal economy, Baldwin picks apart the differences between home and place, suggesting that neither is really about geographical space. Home, he concludes, is a condition that cannot be changed; it is metaphysical, rather than geographical. "There's no place like home," the narrator of Baldwin's short story "This Morning, This Evening, So Soon" hears a passenger declare as they arrive by boat in New York. Baldwin's writing suggests rather than there is no place that is home. ${ }^{22}$ In his essays and fiction, home is frequently invoked to describe an interior space, where the writer meditates on what it means to be at home in the world. It's a condition sometimes called interiority, or as Baldwin might have called it, the mysterious self: a still point in a turning world - or an irrevocable condition-a constant in a changing world. But, as Baldwin reminds us, there is journeying to be undertaken in order to reach this place: "Go back to where you started, or as far back as you can, examine all of it, travel your road again and tell the truth about it. Sing or shout or testify or keep it to yourself: but know whence you came."23

These various projects to recover or preserve Baldwin's home-or conditionare nonetheless important reminders that the writer should not be cloistered away in the attic or dungeon of academe; that greater access to his work should be applauded, from JSTOR to Netflix, where the Oscar-nominated and Bafta-award winning film I Am Not Your Negro can be viewed with ease from the comfort of people's homes, a project that Baldwin began with the working title: Remember This House.

Our fourth volume opens with Jeff Fallis's essay, "'So sensual, so languid, and so private': James Baldwin's American South," which closely examines Baldwin's fictional and nonfictional engagements with the American South. Fallis's essay charts Baldwin's complex and often contradictory negotiations with the construction of identity in white and black Southerners and the South's tendency to deny and 
censor its historical legacy of racial violence. Our following two essays focus attention on manipulations of time and space in Baldwin's writing. Robert Z. Birdwell's essay, "Kairotic Time, Recognition, and Freedom in James Baldwin's Go Tell It on the Mountain," contributes a new perspective on discussions of Baldwin's representation of time and his relationship to Christianity through an analysis of kairos in Go Tell It on the Mountain. Maleda Belilgne's piece, "Sonic Living: Space and the Speculative in James Baldwin's 'Sonny's Blues," meditates on the relationship between Baldwin's assessment of Bessie Smith's "Backwater Blues" and his short story, "Sonny's Blues," arguing that the speculative emerges in Baldwin's story when the sonic overrides a racialized inscription of space.

Dagmawi Woubshet's piece, "Black Meets Black: Encounters in America”, draws on James Baldwin's ideas on race, immigration, and American identity to examine the experience of contemporary African immigrants in the United States. Magdalena J. Zaborowska's essay, "You have to get to where you are before you can see where you've been': Searching for Black Queer Domesticity at Chez Baldwin," argues for the importance of James Baldwin's last house, located in St. Paulde-Vence in the south of France, to his later works, in which Baldwin created unprecedented models of black queer domesticity and humanism that offer novel ways to reconceptualize what it means to be an American intellectual in the twentyfirst-century world. Our essay section concludes with our Graduate Student Essay Award winner, Kelly Shinners, whose essay, "My Dear White Sister," reads Baldwin's work from a personal lens in order to call on fellow white readers and scholars of Baldwin to begin examining the myths of America by first examining themselves.

$J B R$ 's current "Dispatches" section is in two parts. Lindsey R. Swindall's piece, "There is No Texting at James Baldwin's Table," describes the genesis of two fivepart public discussions on the works of James Baldwin that were co-facilitated by Swindall and actor Grant Cooper at two schools in New York City in the 2016-17 academic year. To follow, Mikko Tuhkanen's dispatch, "Losing Real Life," proposes that we turn to James Baldwin's work to assess the cost of, and think alternatives to, the cultures of traumatization whose proliferation one witnesses in contemporary U.S. academia.

We have also included a bibliographic essay by Ernest Gibson, entitled "Trends in James Baldwin Criticism, 2013-15." This essay examines the 2013-15 trends from four vantages: an examination of a return, with revision, to popular work by Baldwin; identifying Baldwin's work as a contributor to theoretical and critical methodology; Baldwin and intertextuality or intervocality; and a new frontier in Baldwin studies. In a familiar turn of events, we conclude volume 4 as we did volume 3, with an interview. "I live a hope despite my knowing better": James Baldwin in Conversation with Fritz J. Raddatz (1978)" is the first English-language publication of an interview with James Baldwin conducted by the German writer, editor, and journalist Fritz J. Raddatz in 1978 at Baldwin's house in St. Paul-de-Vence. This spirited exchange between Baldwin and Raddatz earnestly considers possible parallels between Nazi Germany and U.S. racism, with Baldwin most prominently likening the whole city of New York to a concentration camp. The interview also covers various topics characteristic of Baldwin's interests at the time-among them 
his thoughts about President Carter's presidency, his reasons for planning to return to the United States, his disillusionment after the series of murders of black civil rights activists in the 1960s and 1970s, and the role of love and sexuality in his literary writings.

Finally, in our continuing efforts to explore James Baldwin's life, works, and legacies, JBR is delighted to feature Fahamu Pecou's 2012 painting, Real Negus Don't Die: The Fire Inside, as our cover for volume four.

\section{Notes}

1 James Baldwin: The Price of the Ticket, dir. Karen Thorsen, 1989.

2 James Baldwin, Giovanni's Room (1956) (London, Penguin, 1991), p. 88.

3 Ibid., p. 111.

4 Fred Standley and Louis H. Pratt (eds.), Conversations with James Baldwin (Jackson, MS, University of Press of Mississippi, 1986), p. 256.

5 James Baldwin: The Price of the Ticket.

6 James Baldwin, "Notes of a Native Son" (1955), in Collected Essays, ed. Toni Morrison (New York, Library of America, 1998), p. 83.

7 Ibid., p. 66.

8 James Baldwin, Go Tell It on the Mountain (1953) (London: Penguin, 1991), p. 21.

9 James Baldwin, "The Fire Next Time" (1963), in Morrison (ed.), Collected Essays, p. 294.

10 Ibid., p. 291.

11 Ibid., p. 294.

12 Ibid., p. 340. See Orlando Edmonds, "Why The Fire Next Time Still Matters," JSTOR Daily, 2 November 2016, https://daily.jstor.org/feature-james-baldwin-fire-next-time/ (accessed 26 March 2018).

13 Baldwin's Nigger, dir. Horace Ové (1969).

14 See Rachel Donadio, "Battling to Save James Baldwin's Home in the South of France," New York Times, 4 April 2016, www.nytimes.com/2017/04/04/arts/battling-to-save-jamesbaldwins-home-in-the-south-of-france.html (accessed 26 March 2018).

15 The film was made by Pierre Koralnik and is entitled Un Homme Noir dans un Village Blanc (1963). The film is available at https://youtu.be/wQs9qGb3dI8 (accessed 26 March 2018).

16 James Baldwin, "Stranger in the Village" (1953), in Morrison (ed.), Collected Essays, p. 119.

17 Ibid., p. 121.

18 James Baldwin, “The Discovery of What it Means to be American" (1959), in Morrison (ed.), Collected Essays, p. 138. For a recent account of visiting Leukerbad, see Teju Cole, "Black Body: Rereading James Baldwin's 'Stranger in the Village," The New Yorker, 19 August 2014, www.newyorker.com/books/page-turner/black-body-rereading-james-baldwins-stranger-village (accessed 26 March 2018).

19 James Baldwin, “Everybody's Protest Novel” (1949), in Morrison (ed.), Collected Essays, p. 15.

20 D. Quentin Miller, A Criminal Power: James Baldwin and the Law (Columbus, OH, Ohio State University Press, 2012), p. 12.

21 James Baldwin, “Autobiographical Notes" (1955), in Morrison (ed.), Collected Essays, p. 8. 
22 James Baldwin, “This Evening, This Morning, So Soon” (1960), in Going to Meet the Man (London, Penguin, 1991), p. 149.

23 James Baldwin, "Introduction," in The Price of the Ticket: Collected Nonfiction, 1948-1985 (New York, St. Martin's Press/Marek, 1985), p. xix.

\section{Works Cited}

Baldwin, James, "Autobiographical Notes" (1955), in Collected Essays, ed. Toni Morrison (New York, Library of America, 1998), pp. 5-9. "The Discovery of What it Means to be American" (1959), in Collected Essays, ed. Toni Morrison (New York, Library of America, 1998), pp. 137-42.

"Everybody's Protest Novel" (1949), in Collected Essays, ed. Toni Morrison

(New York, Library of America, 1998), pp. 11-18.

"The Fire Next Time" (1963), in Collected Essays, ed. Toni Morrison (New York,

Library of America, 1998), pp. 291-348. Giovanni's Room (1956) (London, Penguin, 1990).

Go Tell It on the Mountain (1953) (London, Penguin, 1991).

Going to Meeting the Man (1965) (London, Penguin, 1991).

"Notes of a Native Son" (1955), in Collected Essays, ed. Toni Morrison (New York, Library of America, 1998), pp. 63-84.

The Price of the Ticket: Collected Nonfiction, 1948-1985 (New York, St. Martin's

Press/Marek, 1985).

"Stranger in the Village" (1953), in Collected Essays, ed. Toni Morrison (New York, Library of America, 1998), pp. 117-29.

Cole, Teju, "Black Body: Rereading James Baldwin's 'Stranger in the Village," The New Yorker, 19 August 2014, www.newyorker.com/books/page-turner/black-body-rereading-james-baldwins-stranger-village (accessed 26 March 2018).

Donadio, Rachel, "Battling to Save James Baldwin's Home in the South of France," New York Times, 4 April 2016, www.nytimes.com/2017/04/04/arts/battling-to-save-jamesbaldwins-home-in-the-south-of-france.html (accessed 26 March 2018).

Edmonds, Orlando, "Why The Fire Next Time Still Matters," JSTOR Daily, 2 November 2016, https://daily.jstor.org/feature-james-baldwin-fire-next-time/ (accessed 26 March 2018).

Koralnik, Pierre (dir.), Un Homme Noir dans un Village Blanc (1963), https://youtube/ wQs9qGb3dI8 (accessed 26 March 2018).

Miller, D. Quentin, A Criminal Power: James Baldwin and the Law (Columbus, OH, Ohio State University Press, 2012).

Ové, Horace (dir.), Baldwin's Nigger (1969).

Standley, Fred, and Louis H. Pratt (eds.), Conversations with James Baldwin (Jackson, MS, University of Press of Mississippi, 1986).

Thorsen, Karen (dir.), James Baldwin: The Price of the Ticket (1989).

\section{Contributor's Biography}

Douglas Field is senior lecturer in twentieth-century American literature at the University of Manchester. He is the author, most recently, of All Those Strangers: The Art and Lives of James Baldwin (Oxford University Press, 2015). He is the co-founding editor of James Baldwin Review. 